\title{
Growth performance of siamese gourami Trichopodus pectoralis seed with different stocking density to optimize production capacity: optimum temperature and salinity application
}

\author{
Lies Setijaningsih ${ }^{1, *}$, Dewi Puspaningsih ${ }^{1}$, and Imam Taufik ${ }^{1}$ \\ ${ }^{1}$ Research Institute for Freshwater Aquaculture and Fisheries Extention, Jl. Sempur No.1, Bogor, \\ West Java, Indonesia
}

\begin{abstract}
Fulfill needs of Siamese gourami still rely on the catch from nature, so the population in nature has become decreased. The increase of Siamese gourami fish production from culture is still constrained by the survival rate and slow growth rate in the seed phase. The purpose of this research was to determine the effect of Siamese gourami stocking density on the application of optimum temperature and salinity to growth performance for optimization of production capacity. Application of optimum temperature and salinity refers to the results of previous research, i.e., temperature of $28{ }^{\circ} \mathrm{C}$ and salinity $3 \%$. Siamese gourami seed with length of $2.96 \pm 0.42 \mathrm{~cm}$ and weight of $5.27 \pm 0.10 \mathrm{~g}$ used in the research. The experimental design used completely randomized design with four treatments, i.e. 1 fish $\mathrm{L}^{-1}, 2$ fish $\mathrm{L}^{-1}, 3$ fish $\mathrm{L}^{-1}$ and 4 fish $\mathrm{L}^{-1}$. The results showed that there were an effect of different stocking density on absolute growth weight and length, survival rate, specific growth rate and productivity. This is shown in the $\mathrm{C}$ treatment which growth was $4.95 \pm$ $0.037 \mathrm{~g}$, length $3.51 \pm 0.01 \mathrm{~cm}$, survival rate $93.47 \%$, specific growth rate $1.22 \%$ and fish productivity of $625.76 \mathrm{~g}$.
\end{abstract}

\section{Introduction}

Siamese fish commodities are endemic but very potential to be culture, because in addition to being sold as fresh fish in the market, Siamese fish is often preserved in the form of salted fish. Fulfill the needs of Siamese fish still rely on the catch from nature, so the population in nature has decreased. The population decline in nature, indicated by the smaller size of individual Siamese fish caught by the community (Ath-thar et al., 2014). Efforts to increase Siamese fish production from culture are still constrained by the survival rate and slow growth in the seed phase. Problem-solving attempts have been made through the study of aspects of reproductive biology [10]; aspect of feed [14], growth and 
development performance (Prakoso et al., 2014), the influence of water temperature on the culture of Siamese fish [11] and salinity media on fish culture [9].

In the development of siamese gourami culture, approach on physiological factors such as temperature and salinity can improve the performance of fish growth. Temperature may affect fish activity, where temperature fluctuations are closely related to energy use, and feed consumption affects on the growth. Optimal water temperature will increase the activity of fish feeding, thus accelerating of growth [8]. While salinity has an effect on digestibility and growth [13]. The salinity study on growth performance in freshwater fish has been done, but information on optimum temperature and salinity application to support the growth performance of Siamese gourami seed has not existed. The purpose of this research is to determine the growth performance of Siamese gourami Trichopodus pectoralis with the difference of stocking density to optimize production capacity with optimum temperature and salinity application.

\section{Materials and methods}

The research was conducted at Research Installation of Environmental Technology and Toxicology of Freshwater Aquaculture, Research Institute of Freshwater Aquaculture and Fisheries Extension, Bogor, Indonesia. The test fish came from the fish farmer in Jambi with the initial weights of $5.27 \pm 0.10 \mathrm{~g}$ and the length of $2.96 \pm 0.42 \mathrm{~cm}$. This experiment used an experimental laboratories method. The design pattern used was Completely Randomized Design (RAL) consisting of 4 treatments and 3 replications, can be seen in Table 1 .

Table 1. Treatments of difference stocking density on culture of Siamese gourami seed with optimum temperature and salinity application

\begin{tabular}{|c|c|c|c|c|}
\hline \multirow{2}{*}{ Parameters } & \multicolumn{4}{|c|}{$\begin{array}{c}\text { Treatments of difference stocking } \\
\text { density (fish) }\end{array}$} \\
\cline { 2 - 5 } & A & B & C & D \\
\hline Temperature $\left(28^{0} \mathrm{C}\right)$ & \multirow{4}{*}{400} & $\mathbf{8 0 0}$ & $\mathbf{1 2 0 0}$ & $\mathbf{1 6 0 0}$ \\
\hline Salinity 3\%o & & &
\end{tabular}

Trial container is a fiberglass tanks with size of $140 \times 50 \times 50 \mathrm{~cm}$. Restricted feeding is based on FR 5\% biomass and given three times daily. Application of water temperature $28^{0} \mathrm{C}$ refers from the result of the research that the seeds with size of the initial weight of $0.89 \pm 0.06 \mathrm{~g}$ has a $100 \%$ survival rate [11]. Each fiberglass tanks is equipped with heather and for salinity referring to Setijaningsih [9], the optimum salinity 3 ppm gives $97.33 \%$ of survival rate.

The parameters observed during the experiment were the survival rate according to Effendi (2004), the specific growth rate according to Godart (1996), the increase in absolute weight and total length according to Zonneveld [16]. Measurements of water quality parameters include temperature, dissolved oxygen, $\mathrm{pH}$ and ammonia were done every ten days. Data analyzed with variance (ANOVA) to know the effect of interaction between treatment given, if there is difference then Duncan advanced test were done to know which treatment gave highest and lowest result. Water quality parameters data were analyzed descriptively. 


\section{Results and Discussion}

\subsection{Survival rate and specific growth rate}

After passing culture period for 50 days research of optimum temperature and salinity application on Siamese gourami seeds achieved 93.67\% survival rate. The highest survival rate is in the $\mathrm{C}$ treatment with stocking density of 1200 fish (Figure 1). The results of the statistical test, the survival rate value of treatment $\mathrm{C}$ showed significantly different $(\mathrm{P}$ $<0.05$ ) with treatment $\mathrm{A}, \mathrm{B}$ and $\mathrm{D}$, while treatment $\mathrm{A}$ and $\mathrm{B}$ were not significantly different $(\mathrm{P}>0.05)$. The more the amount of food consumed, the growth of fish will increase. Growth will occur when there is excess energy after the energy produced is reduced by energy used for all activities including energy lost through feces and urine. The excess energy is used to build a new tissue that results in growth rate. On the other hand, the low survival rate in the D treatment with density of 1600 fish is assumed to be due to the lack of equilibrium between the energy for movement activity and the energy for growth. Survival rate related to fish comfort will be followed by a specific growth rate (LPS) (Figure 2). The highest LPS value is shown in the $\mathrm{C}$ treatment with $1.22 \%$, with that condition or with Salinity $3 \%$ represents optimal growth because the energy for the ion adjustment process is diverted for metabolism and growth of fish with a value of 0.005 osmol kg $\mathrm{kg}_{2}^{-1} \mathrm{O}^{-1}$ [9], so that it can optimize the growth weight of Siamese gourami seed. But if the salinity is not optimum, then the fish will spend more energy to regulate the osmotic balance [6].

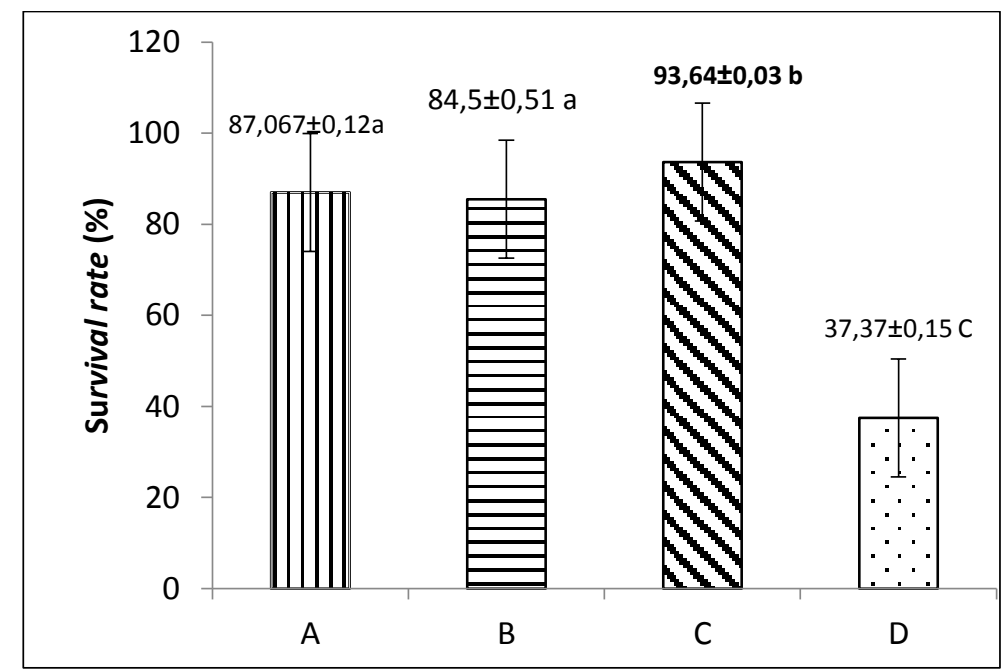

Fig 1. Survival rate of Trichopodus pectoralis 


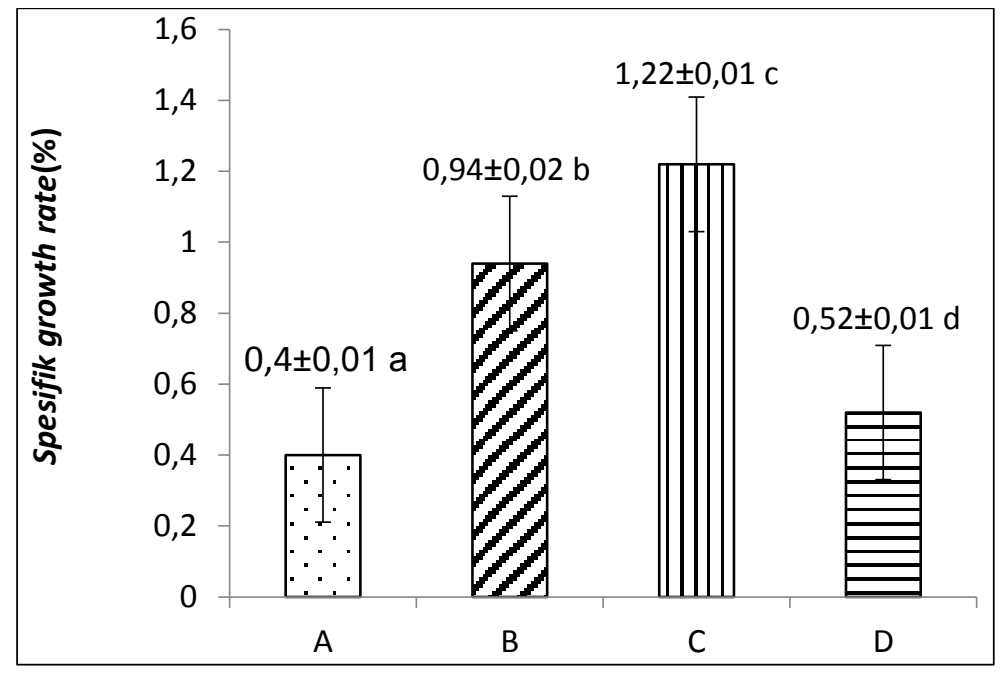

Fig 2. Spesific growth rate of Trichopodus pectoralis

\subsection{Weight and length gain}

The measurement result of weight and length of Siamese gourami seeds during 50 days of culture gave the best result on the $C$ treatment (stocking density 1200 fish) of $4.95 \pm$ $0.037 \mathrm{~g}$ and $3.51 \pm 0.01 \mathrm{~cm}$ (Figures 3 and 4). The result of the analysis of variance showed that the $\mathrm{C}$ treatment was significantly different $(\mathrm{P}<0.05)$ with treatment of $\mathrm{A}, \mathrm{B}$ and $\mathrm{D}$. This means that the increase of Siamese gourami seed weight in treatment C, with 1200 stocking density was influenced by optimum temperature and salinity application, which is better than other treatments. The existence of optimum temperature and salinity application hence no temperature fluctuation which is very influential to the availability of dissolved oxygen and $\mathrm{pH}$ value. While the low weight increase in treatment $\mathrm{D}$, the high of stocking density is suspected to result in the movement of fish so that it can cause inconvenience or fish to be stressful and resulted in disruption of metabolism and growth of fish. The active movement of fish requires stored energy in the body that is used for self-adjustment to adverse environmental conditions, consequently disrupting the metabolic or biological processes [15]. While at treatment A with stocking density 400 fish / tank has low weight gain. When viewed from water quality data, the alkalinity value of treatment A especially at the beginning of measurement and its range is also low enough to cause a decrease in $\mathrm{pH}$ and dissolved oxygen values.

The highest productivity of Siamese fish seeds was achieved at the $\mathrm{C}$ treatment of $1371.04 \mathrm{~g}$, followed by treatment A, B and D of $320.16 \mathrm{~g} ; 642.96 \mathrm{~g}$ and $309.50 \mathrm{~g}$. The result of the analysis of the variation of the productivity of Siamese fish seeds on treatment $\mathrm{C}$ was significantly different $(\mathrm{P}<0.05)$ with treatment $\mathrm{A}, \mathrm{B}$ and $\mathrm{D}$, but treatment $\mathrm{A}$ and $\mathrm{D}$ were not significantly different $(\mathrm{P}>0.05)$. 


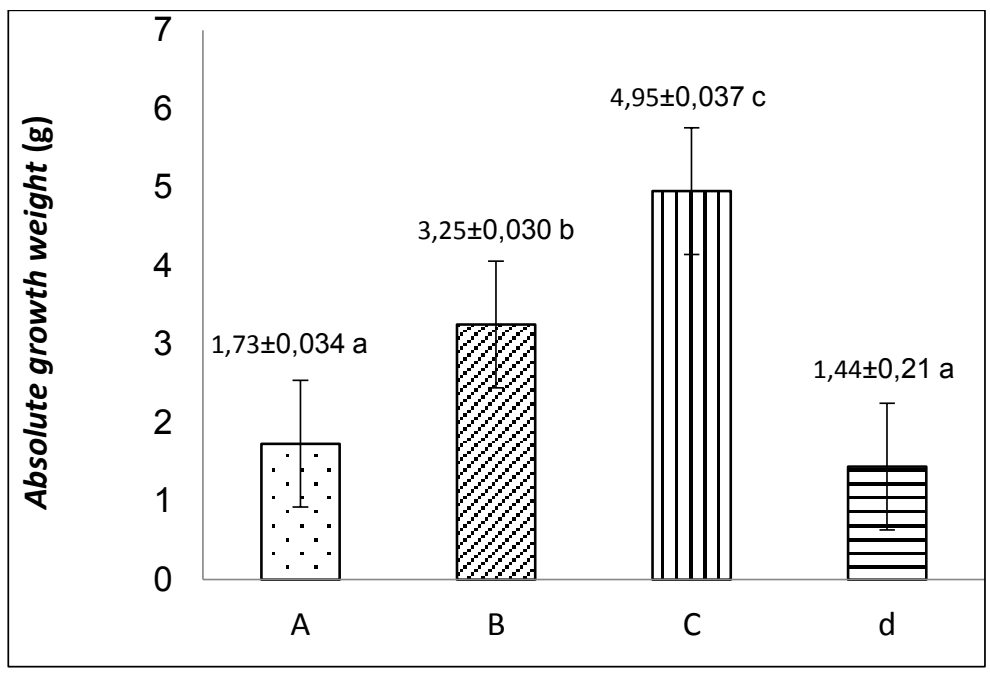

Fig 3. Absolute growth weight of Trichopodus pectoralis

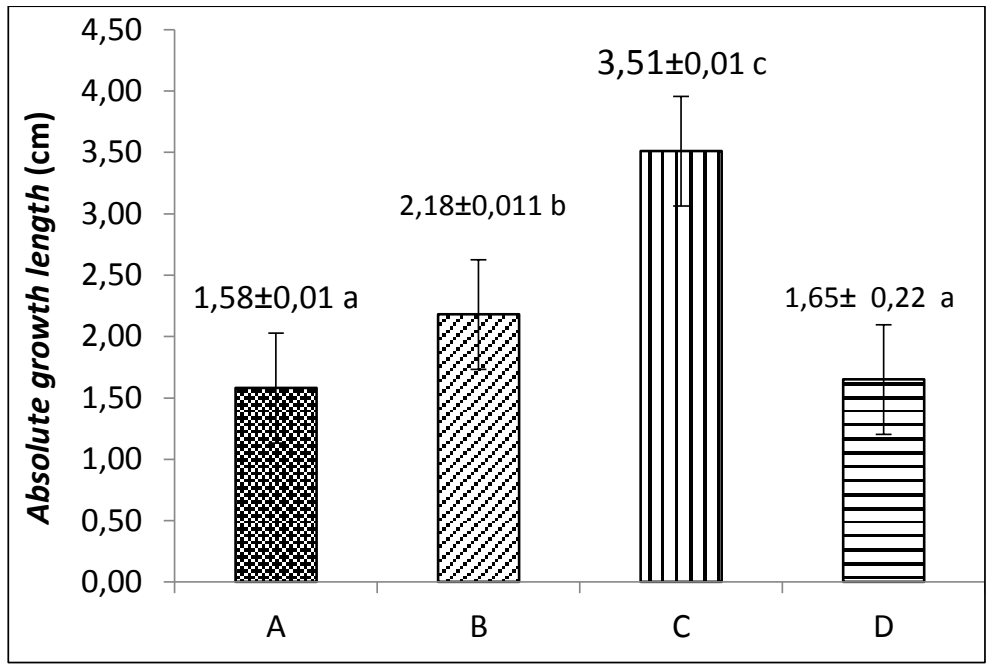

Fig 4. Absolute growth length of Trichopodus pectoralis

\subsection{Blood figure}

The osmotic gradient obtained at all treatments at the beginning of the study achieved at about $0.316 \mathrm{Osmol} \mathrm{kg} \mathrm{H}_{2} \mathrm{O}^{-1}$ and at the end of the study showed a decrease in treatments $\mathrm{A}$, $\mathrm{B}$ and $\mathrm{C}$, while an increase in gradient value was achieved in treatment $\mathrm{D}$ (Figure 5). Osmotic gradients and blood glucose are indicators of fish in comfortable conditions or not in the medium of life. Siamese fish seeds maintained on culture media with optimum temperature and salinity applications are in optimum or non-stressful conditions, whereas fish in stress conditions will cause physiological processes to disrupt and even cause death [12]. In the treatment of A, B and C, the Siamese Siamese fish live with sufficient energy. This is supported by the results of the measurement of dissolved oxygen and $\mathrm{pH}$ value as 
well as the results of biological index measurements such as survival rate, specific growth rate, weight gain and absolute length. The optimum application of temperature and salinity to the culture of fish seeds is shown by the effectiveness of its performance, where the activity of Siamese fish is influenced by the optimum temperature so that the use of energy obtained from feed consumption spur on the growth of fish. In addition, the improved performance of Siamese fish seed growth is also influenced by the optimum salinity application that is by feed utilization which affects the digestibility of feed.

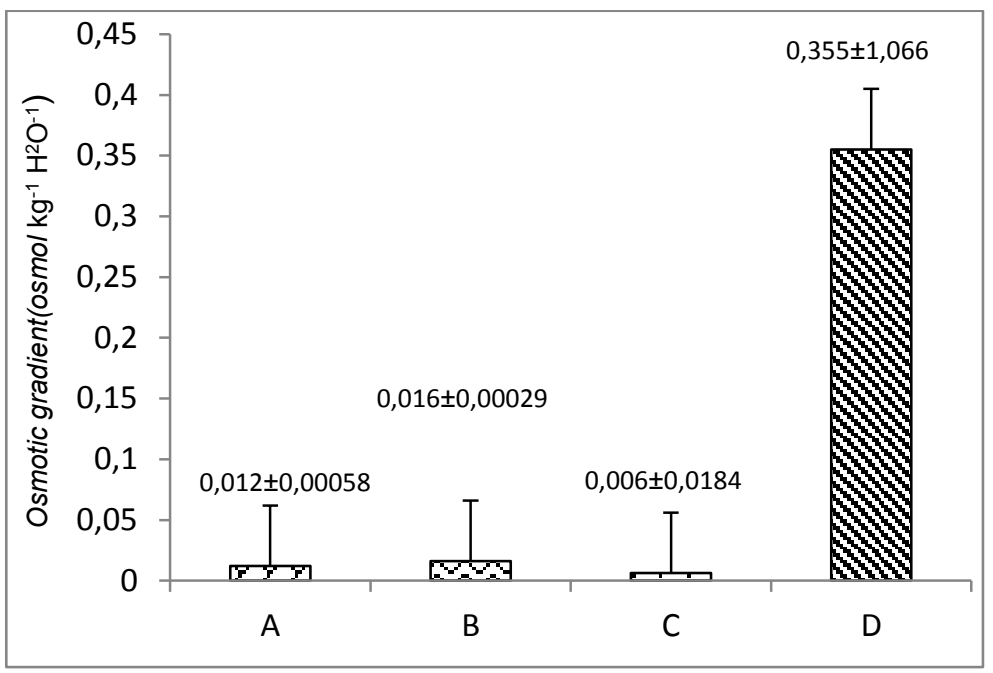

Fig 5. Osmotic gradient of Trichopodus pectoralis

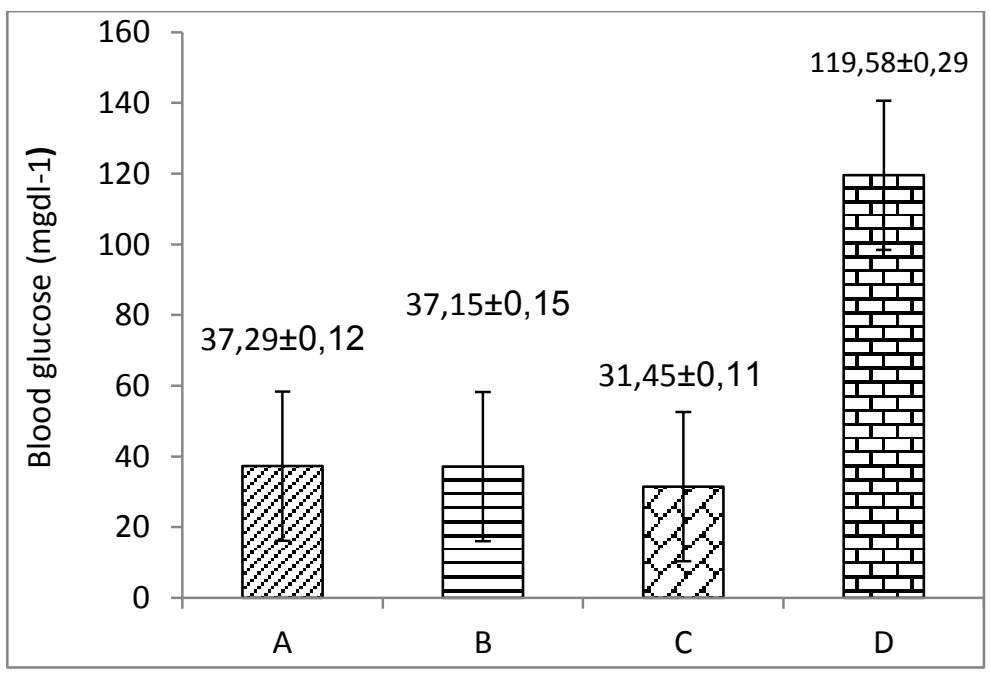

Fig 6. Blood Glucose of Trichopodus pectoralis 


\subsection{Water quality}

The role of water quality parameters becomes one of the supporting factors as well as to increase the growth and survival of fish such as temperature [1]. The optimum temperature and salinity application have an effect on the endurance level of fish. In this research, the highest concentration of oxygen was found in the treatment of $\mathrm{C}$, which was 1200 fish/container, followed by treatment of B (800 fish/container), treatment A (400 fish/container), and D treatment (1600 fish/container) (Table 2). The results of the temperature study on the performance of the growth and survival of Siamese fish seeds showed that the dissolved oxygen content obtained was $4.97-5.19$ at $28^{\circ} \mathrm{C}$ better than at temperatures of $26^{\circ} \mathrm{C}, 30^{\circ} \mathrm{C}$ and $32^{\circ} \mathrm{C}$ [11]. The $\mathrm{pH}$ value at treatment $\mathrm{A}(400$ fish/container), treatment B (800 fish/container) and C (1200 fish/container) ranged from 7.04 - 7.51 (Table 2).

The amount of ammonia excretion stimulated from feed consumption, ammonia excretion will increase when the media temperature to the optimum limit and ammonia excretion decreases when the temperature is more than the optimum limit. At treatment $\mathrm{C}$ was reached the ammonia range of $0.0012-0.0213 \mathrm{mg} \mathrm{L}^{-1}$ and the highest range was achieved at treatment $\mathrm{D}$ of $0.1541-0.269 \mathrm{mg} \mathrm{L}^{-1}$. The data in Table 2 shows the physiological processes of each treatment, which in the treatment $\mathrm{C}$ illustrates the convenience of fish on culture media with optimum temperature and salinity applications. While the range of fish ammonia values is $2.0-6.0 \mathrm{mg} \mathrm{L}^{-1}{ }^{[}$[4] and the normal concentrations of ammonia in uncontaminated waters are below $0.25 \mathrm{mg} \mathrm{L}^{-1}$ and in the polluted waters concentrate below $1,0 \mathrm{mg} \mathrm{L}^{-1}$ [2].

Alkalinity is often referred to as a quantity showing the buffer capacity of the bicarbonate ion $\left(\mathrm{HCO}_{3}{ }^{-}\right)$, at a particular stage to carbonate ions $\left(\mathrm{CO}_{3}{ }^{2-}\right)$ and hydroxide $\left(\mathrm{OH}^{-}\right)$in water. The value of alkalinity during culture ranged from 35.16 to $116.02 \mathrm{mg} \mathrm{L}^{-1}$ $\mathrm{CaCO}_{3}$ (Table 2) and the value was still within the range that could support the survival of Siamese fish seeds. The ideal alkalinity range for pond water culture is $20-120 \mathrm{mg} \mathrm{L}^{-1}$ $\mathrm{CaCO}_{3}[3]$.

Table 2. The value of water quality on culture media of Siamese fish

\begin{tabular}{|c|c|c|c|c|c|}
\hline \multirow{2}{*}{ Parameters } & \multicolumn{4}{|c|}{ Treatment } & \multirow{2}{*}{ Reference } \\
\cline { 2 - 5 } & $\mathrm{A}$ & $\mathrm{B}$ & $\mathrm{C}$ & $\mathrm{D}$ & $\begin{array}{c}23-28 \\
\text { (Froese\&Pauly, } \\
2014)\end{array}$ \\
\hline $\begin{array}{c}\text { Dissolved } \\
\text { oxygen } \\
\left(\mathrm{mg} \mathrm{L}^{-1}\right)\end{array}$ & $3,03-5,67$ & $3,26-6,59$ & $5,92-6,94$ & $2,96-4,23$ & $\begin{array}{c}6,0-8,3 \\
\text { (Froese\&Pauly, } \\
2014)\end{array}$ \\
\hline $\mathrm{pH}$ & $5,74-6,02$ & $7,07-7,51$ & $7,12-7,84$ & $5,65-6,21$ & $\begin{array}{c}2,0-6,0 \\
\text { (Froese\&Pauly, } \\
2014)\end{array}$ \\
\hline $\begin{array}{c}\text { Ammonia } \\
\left(\mathrm{mg} \mathrm{L}^{-1}\right)\end{array}$ & $0,009-0,0143$ & $\begin{array}{c}0,013- \\
0,0245\end{array}$ & $\begin{array}{c}0,0012- \\
0,0213\end{array}$ & $\begin{array}{c}0,1541- \\
0,269\end{array}$ & $\begin{array}{c}\text { (Boyd \& } \\
\text { Tucker, 1998) }\end{array}$ \\
\hline $\begin{array}{c}\text { Alkalinity } \\
\left(\mathrm{mg} \mathrm{L}^{-1}\right.\end{array}$ & $20,16-40,74$ & $\begin{array}{c}35,14- \\
67,52\end{array}$ & $\begin{array}{c}35,34- \\
62,36\end{array}$ & $\begin{array}{c}80,21- \\
116,62\end{array}$ \\
$\left.\mathrm{CaCO}_{3}\right)$ & \multicolumn{3}{|c|}{} & \multicolumn{2}{c}{} \\
\hline
\end{tabular}




\section{Conclusions}

The application of temperature $28^{\circ} \mathrm{C}$ and salinity of $3 \mathrm{ppm}$ gives the optimum value range for the growth of Siamese fish seeds in the stocking density of 1200 fish/container. Optimum growth is supported by optimum values on water quality parameters and blood image.

Our thanks go to Research Institute for Freshwater Aquaculture and Fisheries Extention, Bogor, Indonesia which has funded this research through APBN of Ministry of Marine Affairs and Fisheries of the Republic of Indonesia 2016.

\section{References}

1. F.J. Arjona, L.V. Chacoff, I.R. Jarabo, O. Gonçalves, I. Páscoa, P. María, M.D. Río, J.M. Mancera. Aqua. 87. (2009)

2. C.E. Boyd. Water quality. doi:10.1007/978-3-319-17446-4. (2015)

3. C.E. Boyd, C.S. Tucker. doi:10.1007/978-1-4615-5407-3. (1998)

4. R. Froese, D. Pauly. Fish Base. www.fishbase.org. (2014)

5. S. Goddard. Feed Management in Intensive Aquaculture. 174 (1996)

6. S. Kucuk. Af. J. Biotech. 12, 5 (2013)

7. D.M. Kelabora. Fish.Terrest.J. 38, 10 (2010)

8. N.S. Madinawati, Yoel. Media Litbang Sulteng. 4, 5 (2011)

9. L. Setijaningsih, I. Taufik, T. Prihadi, D. Radona, A. Saputra. Aq. J. Ind. (to be published).

10. D. Oktafia, R.M. Putra, D. Efizon. Reproductive Biology of Trichogaster pectoralis From Flood Plane captured in the Tangkerang Barat District and Delima District. (2014)

11. L. Setijaningsih. Prosiding Simposium Nasional Ikan dan Perikanan. 9 (2017)

12. M. M. Porchas, L. R. M. Cordova, R. R. Enriquez. Pan-Amer. J. Aq. Sci. 4, 20 (2009)

13. D. Rachmawati, J. Hutabarat, S. Anggora. Marine Science. 17, 7 (2012)

14. Siswanto, U. Bijaksana, I. Fitriliyani. J. Fish. Sci. 6, 2 (2016)

15. P.M. Schulte. Ency. Fish. Phys. Volume 3. Energetics, interactions with the Environment, Lifestyles, and Applications. Inggris (GB): Elsevier. 6 (2011)

16. N. Zonneveld, E.A. Huisman, J.H. Boon. The Principles of Fish Cultivation. 318 (1991) 